\title{
Calvin's view on the book of the Acts of the Apostles
}

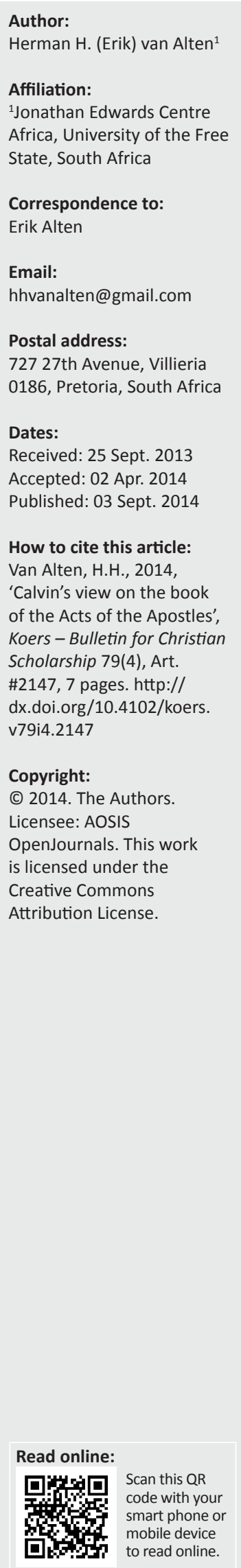

How does John Calvin view the book of the Acts of the Apostles? What does he see as the benefit of this book for the church of his time? Is he, like so many today, of the opinion that the book of Acts is primarily about the work of the Holy Spirit? Calvin preached and commented on the book of Acts from 1549 to 1554 . His commentary is preceded by an Argumentum as well as a number of dedicatory letters (accompanying the respective editions). In these introductory documents Calvin gives the reader insight into his view on the benefit and the theme of Acts. He describes the benefit of the book of Acts primarily from a Christological perspective: the book of Acts paints a picture of the effect that Christ's death and resurrection had after he ascended into heaven. This benefit takes its most visible form in the theme of Acts, which Calvin subsequently identifies: the beginning of the church. The theme of the book of Acts is therefore defined from an ecclesiological perspective. This article demonstrates the value of studying not only Calvin's commentaries themselves, but also the introductory documents that accompanied them. In this way, a clear picture of Calvin's view on the book of Acts is painted.

Calvyn se visie op die boek Handelinge van die Apostels: 'n Ondersoek na Calvyn se gebruik van inleidende dokumente. Wat is Johannes Calvyn se visie op die boek Handelinge van die Apostels? Wat is, vir hom, die waarde van hierdie boek vir die kerk van sy dae? Is hy, soos baie vandag, van mening dat Handelinge in die eerste plek gaan oor die werk van die Heilige Gees? Vanaf 1549-1554 het Calvyn oor Handelinge gepreek en geskryf. Sy kommentaar word voorafgegaan deur 'n Argumentum sowel as verskeie opdragbriewe (wat die onderskeie uitgawes vergesel het). In hierdie inleidende dokumente gee Calvyn insig in wat hy beskou het as die waarde en tema van die boek Handelinge. Hy beskryf die waarde veral vanuit 'n Christologiese perspektief: die boek Handelinge skets vir ons die effek van Christus se dood en opstanding nadat Hy na die hemel opgevaar het. Hierdie effek neem sy mees sigbare vorm in die tema wat Calvyn vir die boek Handelinge identifiseer: die begin van die kerk. Die tema word dus vanuit 'n ekklesiologiese perspektief gedefinieer. Hierdie artikel toon die waarde daarvan aan om nie slegs Calvyn se kommentare te bestudeer nie, maar ook die gepaardgaande inleidende dokumente. Daardeur word Calvyn se visie op die boek Handelinge duidelik vir ons geteken.

\section{Introduction}

On 16 April 1546, the city council of Geneva met to discuss the request that a play, based on the Acts of the Apostles, be presented in Geneva (Naphy 2003:98). This play was written by the Frenchman, Simon Greban, and had already been performed in Bourges in 1536 (Dowden 1914:69).

In two separate letters to Farel, Calvin expressed himself about this matter. On 03 June 1546, he wrote that this performance did not have all the ministers' approval, but at the same time he realised that one cannot deny people every one of their amusements (CO 12, 347). Eventually all the ministers decided that the Council would be advised to allow the play. The date for the performance was set on 04 July 1546. However, Michael Cop did not adhere to this decision, and on 28 June 1546, he used the pulpit seriously to admonish the actors. This nearly caused a great tumult in the city. Shortly afterwards, Calvin wrote about this incident to Farel: 'Our plays narrowly escaped being converted into tragedy ... When the day was coming on, Michael, who had done so once before, instead of preaching, inveighed against the actors' (CO 12, 355-356). Calvin continues to describe how the events unfolded until they were finally resolved. Eventually the play continued, but whether Calvin himself watched it is unknown.

What is clear, however, is that Calvin was not positive about the play on the Acts of the Apostles, though he allowed it. Just a few years later he decided to take on the book of Acts himself. But he rather chose another medium by which to paint a lively picture of the important message of Acts. In fact, he chose two media which ran parallel for almost five years. On 25 August 
1549, Calvin delivered the first sermon in his lectio continua on the book of Acts. He would spend the greatest part of the next 5 years preaching on this book during the Sunday morning services. At the same time, in 1549, he also started his commentary on this book. Nowhere in Calvin's works do commentary and sermons coincide as they do in the case of the commentary and the sermons on Acts (Moehn 2006:199-200). Calvin's commentaries were often preceded by either discussions at the congrégations or lectures given to students. But Calvin's work on Acts provides us with the solitary instance where commentary and sermons, exegesis and preaching, go hand in hand. And the result of this exegetical work on Acts was one of the most extensive commentaries in his series of New Testament commentaries. Calvin himself anticipated that it would be a sizeable volume. On 10 November 1550, he wrote to Farel:

Why do you remind me of Acts and Genesis, embryos hardly yet conceived in the womb? I am ashamed to confess how slowly I am getting on with Acts. I have only done a third (ex tertia parte) of it, and what I have written is so long that I foresee it will all be a big volume. I have had to give up Genesis for the time being. $(\mathrm{CO} 13,655)^{1}$

This article will focus, however, neither on Calvin's commentary nor on his sermons on the book of Acts. Instead, a few small documents (the Argumentum and the dedicatory letters), which were attached to his commentary on Acts, will be investigated in order to establish how Calvin viewed the book of Acts. Was it just history that could be enacted in a play, or was there more to this book?

\section{The benefit and theme of the book of Acts}

What are for Calvin the specific characteristics of the book of Acts? What distinguishes this book from other books of the Bible? In order to answer these questions, and thereby set up his commentary, Calvin mainly uses the Argumentum, ${ }^{2}$ and, to a lesser degree, the dedicatory letters. Although not absent in the commentary proper, the reader will find little conscious reflection on these 'preliminary' matters.

\section{A Christological benefit: The effect of Christ's death and resurrection}

From the outset of his Argumentum, Calvin makes it clear that he wants all the godly (pii omnes) to read the book of Acts. In order to promote the reading of Acts, Calvin sets himself the task of briefly showing the benefit (utilitas) of this history (COR XII/1, 11, 1-3), something which he, indeed, does. However, Calvin insists that he does not merely want to repeat those things that commonly (communiter) belong to all the sacred histories (sacrae historiae), but that he will only mention those things that are particular (propria sunt) to this

1.English translation in Parker (1993:29).

2.With the Argumentum is meant the introduction in which Calvin sets out the background and theme of a particular book. specific book (COR XII/1, 11, 17-19). For Calvin the things which are peculiar to this specific book, and which Luke sets down here, are great things and of extraordinary benefit (magna sunt ac rarae utilitatis) (COR XII/1, 11, 20) - again, the word utilitas is used.

However, in his attempts to show his readers the benefit of the book of Acts, the reformer is aware of the fact that Satan has always tried to erase the memory of this history from the minds of the believers; Satan either wants believers to forget about this history or he tries to discredit this history in their minds. He does this by using people to infect the true historical facts with fictitious stories about the apostles and their actions (COR XII/1, 13, 23-29). Satan wants to rob believers of any certainty about the history that followed Christ's ascension (COR XII /1, 14, 8-9). This last statement is crucial to Calvin's understanding of the benefit of the book of Acts, as he immediately afterwards comes to the following conclusion:

So, if this record of Luke (Lucae monumentum) was not in existence, Christ could have appeared to have left no effect (fructum) of his death and resurrection on earth, after He had been lifted up to heaven. For everything would have vanished along with his body. (COR XII/1, 14, 9-12)

Here Calvin comes to the core of what he views as the particular benefit of the book of Acts. The benefit of Acts has everything to do with the continuous effect (fructum) of Christ's earthly work after his ascension. ${ }^{3}$ The book of Acts provides its readers with concrete knowledge of the fruit that Christ's earthly work yielded after he ascended into heaven. That, to Calvin, is the most important benefit of this sacred history. Calvin's view on the benefit (the utilitas) of the book of Acts is, therefore, determined by his Christology, ${ }^{4}$ his view on the all-important place of the Person and work of Jesus Christ. ${ }^{5}$

After stating that, if Luke's record (Lucae monumentum) was not in existence, Christ could have appeared to have left no effect of his death and resurrection, Calvin goes on to describe what he considers to be the effect of Christ's earthly work after his ascension (starting every time with nesciremus): we would not have known that Christ was received into heavenly glory, whilst still maintaining his rule on earth; we would not have known that the doctrine of the Gospel was proclaimed through the ministry of the apostles, starting from Jerusalem and eventually reaching us ( $a b$ ipsis ad nos); we would not have known that the Spirit inspired (afflatos) the apostles so that they only taught what came from God (COR XII/1, 14, 12-17). In these different aspects Calvin explains what he sees as the effect of Christ's death and resurrection after his ascension.

3.See also Institutes 2.16.14-16, where Calvin speaks about the benefit of Christ's ascension.

4.Christology is here used in the broad sense of the word, not only referring to the person and work of Christ, but also to the application of his work through the powe of the Spirit. This overlaps with the soteriological and pneumatological doctrines, of the Spirit. This overlaps with the soteriological and pneumatological doctrines, 258), and his pneumatology is fully Christological (Van't Spijker 2004:104).

5.Often the Acts of the Apostles is viewed as a book about the Holy Spirit; however, for Calvin, Christ is the acting Person in the book of Acts. This is due to the fact that Calvin's doctrine of the Spirit is determined from his Christology. See Balke that Calvin's doctrine of the Spirit is deter
(1983:32-33), Van't Spijker (1988:73-106). 
The first effect of Christ's death and resurrection after his ascension is that he was received into heavenly glory, where he was declared as the highest King of heaven and earth (COR XII/1, 12, 2-3), whilst still maintaining his rule on earth as the perpetual Governor (gubernator) of his church (COR XII/1, 11, 23). Christ's ascension was, therefore, not his departure from this world, but rather his enthronement as King. That is the reason why Calvin can say that the book of Acts depicts the beginning of his reign and, as it were, the renewal of the world (COR XII/1, 11, 26-27). ${ }^{6}$

Ascension for Calvin means that Christ accepted his kingship and that already now, from the mystery of heaven, he governs his church and is near to it through Word and Spirit. With Calvin the ascension of Christ and his sitting at the right hand of the Father are the inauguration of the kingship of the exalted Lord (Van der Kooij 2009:262).

The second effect of Christ's death and resurrection after his ascension pertains to the spreading of the Gospel from Jerusalem to the ends of the earth through the ministry of the apostles. This effect actually contains three distinct and important aspects, namely the spreading of the Gospel, the central role of preaching and teaching, and the task of the apostles. Calvin quotes from Isaiah 2:3 to prove that the Word of the Lord would go out from Jerusalem; but from there, he says, it even reached us, although through a variety of hands (COR XII/1, 14, 14-19). In fact, the whole world was brought into submission by the sound of the Gospel (COR XII/1, 12, 6-7). This last statement immediately highlights the central role of preaching and teaching (the sound of the Gospel). The church came into existence in its proper form (legitima forma) only once the apostles, empowered by the Spirit, started preaching the death and resurrection of their Shepherd, Jesus Christ (COR XII/1, 11, 29-31). With the humble sound of these human voices God achieved more than when he would have thundered from heaven (COR XII/1, 12, 11-14). This, of course, says nothing about the apostles themselves, as they were men of no importance and endowed with no skill; but it shows instead the power of the preaching of the Gospel (COR XII/1, 12, 5-6). But still the apostles carried out with fortitude and steadfastness what was commanded them by God (COR XII/1, 12, 29-31).

The third and final effect of Christ's death and resurrection after his ascension has to do with the work of the Spirit. He was sent to the apostles from above as the fulfilment of Christ's promise and as proof of Christ's presence with and governance of his own (COR XII/1, 11, 21-25). He was the new power (nova virtute) which enabled the apostles to preach (COR XII/1, 11, 30).

In summary, it can be said that, according to Calvin, the benefit (utilitas) of the book of Acts is that it paints a lively picture

6.See also Calvin's explanation of the ascension of Christ in Institutes 2.16.14.

7.Calvin's use of terms such as ostendunt, depingitur, recensetur in his Argumentum indicates that, for him, Acts is not a static description, but rather a lively picture. The indicates that, for him, Acts is not a static description, same is also clear from the dedicatory letter to Radzivil (originally to Christian III), where Calvin says that Luke draws a living pictur (VIvam the Gospel and the fellowship of the believers (COR XII/1, 5, 7). Shortly afterwards, he confirms this in a negative way when he says that the book of Acts does not give an empty picture (inani pictura) (COR XII/1, 5,13). (and thereby knowledge) of the effect (fructum) that Christ's work on earth had after he ascended into heaven. This effect is the royal reign of Christ from heaven, the coming of the Spirit, and the preaching of the Gospel by the apostles to the ends of the earth. In these aspects, as they are described in the book of Acts, Calvin sees the continued effect of Christ's death and resurrection after his ascension, something which Satan would have wanted us to be without. Calvin's view on the benefit and value of the book of Acts is therefore determined by his Christology. Subsequently he can end the Argumentum by saying that this book originated from the Holy Spirit, and must be regarded as a vast treasure (ingentis thesauri) (COR XII/1, 14, 20).

\section{An ecclesiological theme: The beginning of the church}

The effects of Christ's death and resurrection on earth after his ascension - that is the reign of Christ from heaven, the coming of the Spirit, and the preaching of the Gospel by the apostles - receives its most visible shape in what for Calvin is also the theme of the book, namely 'the beginning of the church'. Several times in the Argumentum to his commentary Calvin indicates 'the beginning of the church' as the theme of Acts (Moehn 2006:213).

Whereas secular history is generally praised as an 'instructress of life ${ }^{\prime}{ }^{8}$ the sacred histories (sacrae historiae) deserve even more praise as they not only regulate the external life of man, but also show that God has taken care of his church from the beginning (ab initio) (COR XII/1, 11, 5-11). Thus, Acts is classified as sacred history, specifically telling its readers the narrative of the beginning church through the providential care of God.

Calvin goes on to define God's care for his beginning church more precisely as the beginning of the reign of Christ (regni Christi initium) (COR XII/1, 11, 26-27). ${ }^{9}$ At his ascension Christ was declared as the highest King of heaven and earth (COR XII/1, 12,1-2), and through the subsequent descent of the Holy Spirit He is present with his own and always governs his church (COR XII/1, 11, 23-24). The ascension of Christ is the cause of the 'origin and progress' (origo et progressus) of the church (COR XII/1, 12, 2-3). God's care for his beginning church is, therefore, not just something, but Someone - Jesus Christ, the King of heaven and earth, through the presence of his Spirit. It is clear that the beginning of the reign of Christ (the beginning of the kingdom) and the beginning of the church are intricately connected.

Calvin, however, defines even further what he means by Christ's reign over his fledgling church. Before his ascension Christ had, of course, already gathered some of his church by his preaching, but:

8.Cicero, in De Oratore 2, 9, 36; also cited by Calvin in his commentary on Romans $4: 23$ (CO 49, 86).

9.This link is established when Calvin says about the sacred histories that they show (ostendunt) that God has cared for his church from the beginning, and shortly af terwards he says that the things that Luke sets down here depict (depingitur) the beginning of the reign of Christ. 
the Christian church began to exist (extare coepit) in its proper form (legitima Christianae Ecclesiae forma) only when the apostles were endowed with new power, and preached that that unique Shepherd had both died and been raised from the dead ... (COR XII/1, 11, 27-30)

For Calvin, therefore, the apostles' preaching of the Gospel through the power they received (i.e. the Holy Spirit) signals the true beginning of the church. On the contents of the apostles' preaching, Calvin does not digress much in the Argumentum. After merely mentioning the apostles' speeches and summarising their contents in a single paragraph, he summarily disposes of the topic (ut doctrinae sanae et purae explicationem nunc omittam) and rather recommends the book of Acts for its specific benefit of providing the reader with knowledge of the beginning of the Christian church (quale fuerit Christianae Ecclesiae exordium) (COR XII/1, 13, 13-15).

From the above it can be deduced that, for Calvin, the beginning of the church forms the central theme of the book of Acts. Calvin has a Christological view on the benefit of the book of Acts, but the theme of the book is ecclesiological. And, as has been stated above, the beginning of the church is intricately linked to the beginning of Christ's heavenly reign (i.e. the beginning of his kingdom) as well as to the beginning of the apostles' preaching of the Gospel through the power of the Spirit. Thus, the beginning of the church as central theme in the book of Acts does not happen in isolation, but is linked to ascension, outpouring and proclamation.

This theme ('the beginning of the church') receives a very specific application in the respective dedicatory letters that Calvin wrote to his commentary. In them he connects the beginning of the church, as described in Acts, to an analogous beginning of the church in the country where the dedicatee played a substantial role. According to Calvin, this connection serves to encourage the recipient of his commentary. ${ }^{10}$

In the first dedication, to King Christian III of Denmark (1552), Calvin urges the king to strengthen his conscience by considering the pattern (ratio) and nature (natura), the state (status) and condition (conditio) that the kingdom of Christ had in the beginning ( $a b$ initio). Such a consideration will highlight two things in particular, namely the teaching of the Gospel by which Christ gathers and governs his church, as well as the fellowship of the believers. In the Acts of the Apostles Luke draws a living picture of both (CO 14, 293).

Eight years later (in 1560), Calvin re-uses the exact same words in his dedicatory letter to Nicolas Radzivil. After he has exhorted Radzivil, who embraced the pure teaching of the Gospel in the beginning (initio), to persevere to the end of this course (COR XII/1, 4, 7-10), and has praised him for the services he rendered to the church in Poland in its beginning (Ecclesiae primordiis) (COR XII/1, 4, 13-15), he introduces the same encouragement as was originally given to Christian III.

10.See CO 14, 293 (letter to Christian III; also taken up in the letter to Radzivil, COR XII/1, 4, 29-30); CO 15, 16 (letter to Frederick II); CO 15, 16 (letter to Frederick II; also taken up in the letter to Radzivil, COR XII/1, 6, 7-9).
Calvin wants Radzivil to be encouraged and supported by looking at the kingdom of Christ as it was in the beginning (ab initio) (COR XII/1, 5, 1-3).

In his dedication of part 2 of his commentary on Acts to Prince Frederick II of Denmark (1554) Calvin explicitly states that he thought it suitable to connect (coniungere) the young crown prince to the narrative of Acts, which tells of the very beginnings of the church right from its actual birth (natalibus ecclesiae christianae), and then its advances and increases. That is also the reason why Calvin decided to divide his commentary into two books: so that Frederick could also be part of the narrative. Frederick might be encouraged by the precise resemblance between the reborn church of Denmark (renascentis ecclesiae), which the Lord has committed to his protection, and the church in Acts (CO 15, 16). Only a few moments later, Calvin stresses the same point again. It is particularly useful, he says, to look to the origin of the church (in ecclesiae originem) as Luke describes it. This usefulness lies in the portrayal of the wonderful power of God as well as the endurance of his servants $(\mathrm{CO} 15,16)$. As with the encouragement to Christian III, these words are also taken up verbatim in the dedication to Radzivil (COR XII/1, 6, 8-9).

It is clear that Calvin's letters to the respective dedicatees, especially those addressed to Christian III and Frederick II as being the original dedicatees, were not detached from the contents of the accompanying commentary. Instead, they were intricately linked to what Calvin deemed to be the central theme of the book. The gap of 15 centuries is bridged in order to link two beginning churches - the beginning church in Acts and the beginning church in Calvin's own time. The latter is urged to study and follow the example of the former. ${ }^{11}$

\section{More than one beginning}

The question then arises where Calvin places the real beginning of the church. His strong emphasis on the beginning of the church in Acts could suggest that, for him, the church actually started at that time. However, Calvin fully acknowledges the existence of the church before the time of Acts. In the dedication of his commentary on Genesis to Duke Henry of Vendomme (1563), for example, he clearly states that God after the fall of humanity adopted to himself a church (CO 20, 119). And in the light of the abovementioned connection between the beginning of Christ's reign and the beginning of the church, it is significant that Calvin, in his dedicatory letter to Radzivil, says that the Son of God has always reigned as King from the beginning of the world (COR XII/1, 5, 10). This implies the existence of a people from the beginning of the world. But how, then, should Calvin's emphasis on the beginning of the church in Acts be understood?

For Calvin the church does not have only one beginning. Instead, God has made several new beginnings throughout

11.Calvin's exegetical method of bridging the gap between the biblical context and his own time is widely recognised. See, for example, Bouwsma (1988:91), Harms his own time is widely recogn
$(2010: 11)$, Moehn $(2006: 202)$ 
the history of the Old and the New Testament. ${ }^{12}$ For this ecclesiological perspective, Calvin's view on the unity of the Old and the New Testament is determinative (Harms 2010:51-54). The reformer asserts that the old and the new covenants do not differ, but that they are completely one and the same. He does accept the differences which Scripture mentions, but these should not detract in any way from the unity that has already been established (CO 2, 329). When he discusses the differences - more as an appendix (appendicis) than as the main argument (CO 2,313) - Calvin describes the Old Testament as the childhood of the church and the New Testament as the church's adulthood. ${ }^{13}$ In the progression from childhood to adulthood there is more than one time when God makes a new beginning with his church. Calvin speaks of these new beginnings as new births or rebirths (Harms 2010:98). For him the exodus from Egypt, the return from the Babylonian exile and the first coming of Christ represent the most important beginnings.

The exodus from Egypt is the first of God's new beginnings with his church. In his commentary on Hosea 11:1 Calvin discusses this historical exodus from Egypt. Before the exodus, and during the stay in Egypt, God's church was almost extinguished; Egypt was like a grave without any spark of life. That was exactly what God wanted before he redeemed his church. Israel's coming out of Egypt was, therefore, the nativity (nativitas) of the people. The people were marvellously restored, as if from death to life (COR XII/1, 181, 13-14). This, according to Calvin, is the language Scripture uses when it speaks about the liberation of the people (CO 42, 432) ${ }^{14}$ Something similar can also be found in Calvin's commentary on Isaiah 43:19:

The redemption from Egypt may be regarded as having been the first birth of the church (prima ecclesiae nativitas), because the people were gathered into a body and the church was established ... $(\mathrm{CO} 37,94)$

Calvin continues commenting on the same verse in Isaiah 43 by saying that, after the first birth of the exodus, the liberation from Babylon was a new birth. In his commentary on Daniel 8:1 Calvin explicitly calls the return from the Babylonian exile the second birth of the church (secunda ecclesiae nativitas). This second redemption (the exodus is implied as the first) was the beginning of a new life (CO 41, 87). ${ }^{15}$

In exactly the same way Calvin can speak of the birth of the church in Acts. In his letter to Frederick II he speaks of his desire to connect the crown prince to the narrative of Acts, which embraces the very beginnings (prima ... exordia) of the church, right from its actual birth (natalibus) $(\mathrm{CO} 15,16)$.

12.For similar thoughts on this issue, see also Harms (2010:96-100), Wilcox (1993:118-123).

13.Cf. Institutes 2.11.1-2, 5, 11-13; commentary on Acts 21:21, COR XII/2, 205, 23 25; commentary on Joel $3: 18-19$, CO 42,598 . This theological perspective on the neutical principal in Calvin's exegesis, especially when it concerns his ecclesiology: see Harms (2010:51).

14.See also commentary on Hosea 2:14, CO 42, 241.

15.See also Wilcox (1993:158ff.).
However, from the above it is clear that this birth in Acts should not be literally understood as the first, but as part of a series of beginnings that is connected to the preceding history of God's liberation of his people:

... in the reformer's view of the church the language of birth and renewal of the church is descriptive, not abstract ... The reformer's intent is much less to abstractly locate one particular point in history than to point out the inseparable union between God (Christ) and his church from beginning to end. (Harms 2010:98)

\section{The beginning of a process}

When viewing the beginning of the church in Acts as part of a series of beginnings which marks the history of God's liberation of his people, it is important to take note that, for Calvin, these beginnings are not merely momentary events, but rather the initiation of different processes. This can be seen when his comments, as referred to above, are looked at more closely.

When speaking in his commentary on Isaiah 43:19 about the exodus from Egypt as the first birth, Calvin stresses that this liberation is not limited to the time when the people went out of Egypt, but that it is continued (continuator) down to the possession of the land of Canaan, until the time when the kings had been driven out (CO 37, 94-95). Calvin applies the same principle to the return from the Babylonian exile. The restoration (instauratio) from exile must not be limited to the departure from Babylon, but must be extended (extendenda) to Christ (CO 37, 95). Whenever the prophets spoke about the deliverance from exile, they extended their thoughts and their prophecies as far as the coming of Christ (CO 41, 87).

In a very unique way Calvin also applies this principle to the new beginning of the church which started with the ascension of Jesus Christ, as described in the book of Acts. Again the by now well-known letter to Frederick II is helpful. Calvin wants to connect Frederick to the narrative of the church in Acts, which embraces not only its very beginnings, but also its advances (progressus) and increases (incrementa) $(\mathrm{CO} 15,16)$. And in the Argumentum Calvin states that the Acts of the Apostles review both the origin and the progress (origo et progressus) of the church, from the ascension of Christ (COR XII/1, 12, 2-3). For Calvin the beginning of the church since Christ's ascension is a work of continued progress and growth.

In the cases of the exodus from Egypt and the return from the Babylonian exile Calvin provides clear end-dates for the process of the new beginning - the possession of the land in the case of the exodus, and the coming of Christ in the case of the exile. Does he provide something similar in the case of the newborn church in Acts?

As has already been shown, the beginning of the church in Acts coincided for Calvin with the ascension of Christ, the outpouring of the Spirit and the proclamation of the Gospel by the apostles. Therefore, he primarily extends the new 
beginning in Acts to the whole of the apostolic era with the accompanying promulgation of the Gospel (Wilcox 1993:120). When talking about the beginning of the reign of Christ in his commentary on Daniel 7:8, Calvin immediately defines this as the preaching of the Gospel, which was commenced under Caligula, Claudius, Nero and their successors (CO 41, 50). The apostles had the task of setting up the kingdom everywhere, through the spreading of the Gospel (CO 2, 779).

However, in his comments on the apostle Peter's words in Acts 3:21 ('the times of restoration', ad tempora restitutionis), Calvin says that the restoration is still in process of completion. In this context he says that the kingdom of Christ had just begun, and the perfection of it is deferred until the last day (COR XII/1, 106, 24-28). Thus, the new beginning of the church in Acts provisionally extends to the end of the apostolic era, but reaches its full completion only on the last day. This is the long-term perspective of what has been started in Acts. It is clear that for Calvin the new beginning in Acts is the beginning of a process which extends until the second coming of Christ.

Within this drawn-out process Calvin can also position the church of his own days. Therefore, in the letter to Frederick II, he can speak about the actual birth of the church in Acts, and in the same sentence speak about the reborn church (renascentis ecclesiae) in Denmark, in which Frederick plays a leading role $(\mathrm{CO} 15,16)$. In this way the beginning church in Denmark gets its place in the work of progress from the apostolic era until its completion on the last day.

\section{The coming of Christ}

For Calvin the beginning of the church in Acts forms part of a series of beginnings, more specifically a series of beginning processes. This does not mean, however, that the reformer regards all of these beginnings as on the same level. It is clear that the coming of Christ is the definitive aspect that raises the beginning of the church in Acts above any other beginning or rebirth of the church in the history of God's people. In his commentary on Hosea 11:1, Calvin says that 'the full nativity of the church (plena nativitas ecclesiae) was when Christ came from Egypt to redeem his church' (CO 42, 433). ${ }^{16}$ And he comments on Isaiah 43:19 that he has no doubt that the second redemption (referring to the coming of the Messiah) far surpasses the first redemption (referring to the return from exile, with all the difficulties accompanying it) (CO 37, 95). For Calvin, the coming of Christ marks the beginning of a Golden Age for the church (CO 31, 800).

However, it is necessary to be even more precise. For although Calvin states that the full nativity of the church was when Christ came from Egypt to redeem His church (Hs 11:1), he also indicates that we should trace the origin and the progress of the church to the ascension of Christ, by which He was declared King of heaven and earth (COR XII/1, 12,1-3). ${ }^{17}$ Whilst seemingly speaking in general about Christ's coming and the beginning of the church in the 16.See Harms (2010:98)

17.See also the letter to Frederick II, CO 15, 16.
Old Testament commentaries, Calvin focuses the beginning of the Church in the commentary on Acts specifically on the ascension of Christ. And to narrow it down ever more in the same commentary, he says that the Christian church began to exist in its proper form (legitima forma) only when the apostles were endowed with new power and subsequently started preaching (COR XII/1, 11, 29-31). Thus, whilst it seems that Calvin, in several Old Testament commentaries, can speak in broader terms about the beginning of the church in the time of the coming of Christ, he is more specific when he comes closer to the actual event in the commentary on Acts. As much as the beginning of the church has to do with Christ's death and resurrection in general, the epicentre of the beginning of the church lies with the outpouring of the Spirit at Pentecost. This is, of course, no contradiction, as Pentecost was also initiated by Christ. Christ and his Spirit do not stand against each other, because the Spirit was sent by Christ in order to implement his governance of his church (COR XII/1, 11, 21-24). ${ }^{18}$

\section{Conclusion}

Calvin used the Argumentum and the dedicatory letters to his commentary on Acts to explain to his readers his view on the specific benefit and theme of this particular part of Scripture. It could prove useful to investigate the same genre of documents as they preceded the other commentaries, in order to ascertain whether similar information could be extracted from them. ${ }^{19}$

For Calvin the book of Acts renders a Christological benefit. It shows us the effect that the work of Christ, which he did whilst on earth, had after his ascension. It is important to note that Calvin does not separate Christ from his Spirit, Whom he sent following his ascension. The ascended Christ reigns from heaven through his Spirit and through the preaching of his Word. This is something different from the almost exclusive focus on the work of the Holy Spirit in Acts that we often find in our time, according to which Christ is confined to the heavenly realms. In Calvin's view, however, Christ's reign from heaven is central to the book of Acts.

The beginning of the church, which directly flows from the above benefit, is identified by Calvin as the theme of the book of Acts. This beginning should be understood as part of a series of beginnings (rebirths), whereby Calvin shows his historical understanding of the church. However, the beginning of the church in Acts is unique through the coming of Christ. It is through His coming that the Spirit was poured out and the Gospel started to be preached. That resulted in the beginning of the church in its proper and legitimate form.

It is clear that, for Calvin, Christ, Spirit, preaching and church, are all intertwined. The one flows from the other, and the one cannot be understood apart from the other. This gives Calvin's view on the book of Acts a grand and unified feel,

18.See also Commentary on Acts, COR XII/1, 22, 10-14, Balke (1983:32-33).

19.This has been done by Muller (2000:21-38), with the broader purpose of trying to establish Calvin's exegetical and theological agenda, but not to ascertain Calvin's view on the benefit and theme of a specific part of Scripture. 
and it carries an important message for the church today, as it did for the dedicatees of his commentary. Calvin's ability to bridge the gap between the first and the sixteenth century enables the church today to see herself as part of the process of restoration which was initiated at the coming of Christ and which will be completed at his return. Just as in the first and the 16th century, this work of restoration needs to be done by the Spirit and through the preaching of the Word.

\section{Acknowledgements Competing interests}

The author declares that he has no financial or personal relationship(s) that may have inappropriately influenced him in writing this article.

\section{References}

Balke, W., 1983, 'Calvijn en de Pinksterprediking', in J. van Oort, A. de Reuver M. Verduin (reds.), Verbi Divini Minister, pp. 19-43, Uitgeverij Ton Bolland, Amsterdam.

Bouwsma, W.J., 1988, John Calvin: A sixteenth century portrait, Oxford University Press, New York.

Calvin, J., 1863-1900, Ioannis Calvini Opera Quae Supersunt Omnia, Vol. I-LIX. G[W] Baum, E. Cunitz \& E. Reuss ediderunt, Vol I-LIX. In Corpus Reformatorum, Vol. XXIXL-XXXVII. Brunsvigae/ Berolini: C.A. Schwetschke et filium. [= CO 1-59]
Calvin, J., [1552/1554] 2001, [Commentarium in Acta Apostolorum, Liber Primus et Liber Posterior. Edidit Helmut Feld. (Ioannis Calvini Opera Omnia: Denuo recognita et adnotatione critica instructa notisque illustrata, Series II: Opera recognita et adnotatione critica instructa notisque illustrata, Series II: Opera
Exegetica Veteris et Novi Testamenti, Volumen XII/I et XII/2. Auspiciis Praesidii Conventus Internationalis Studiis Calvinianis Fovendis ediderunt B.G. Armstrong, C. Augustijn, I. Backus, O. Fatio, H. Feld, F.M. Higman, W.H. Neuser, B. Roussel, W. van 't Spijker \& D.F. Wright). Genève, Droz. [= COR II/XII/1 \& COR II/XII/2]

CO see Calvin, J., Ioannis Calvini Opera Quae Supersunt Omnia, ...

COR see Calvin, J., Commentarium in Acta Apostolorum, ...

Dowden, E., 1914, A history of French literature, William Heinemann, London.

Harms, F.A.V., 2010, In God's custody: The church, a history of divine protection, Vandenhoeck \& Ruprecht, Göttingen. (Reformed Historical Theology, vol. 12).

Moehn, W.H.Th., 2006, 'Calvin as commentator on the Acts of the Apostles', in D.K. McKim (ed.), Calvin and the Bible, pp. 199-223, Cambridge University Press, Cambridge. http://dx.doi.org/10.1017/СBO9780511606908.009

Muller, R.A., 2000, The unaccommodated Calvin: Studies in the foundation of a theological tradition, Oxford University Press, New York.

Naphy, W.G., 2003, Calvin and the consolidation of the Genevan reformation, Westminster John Knox Press, Louisville.

Parker, T.H.L., 1993, Calvin's New Testament commentaries, 2nd edn., T\&T Clark Ltd, Edinburgh.

Van der Kooij, C., 2009, 'Christology', in H.J. Selderhuis (ed.), The Calvin handbook, pp. 257-267, William B. Eerdmans Publishing Company, Grand Rapids/Cambridge.

Van 't Spijker, W., 1988, 'The doctrine of the Holy Spirit in Bucer and Calvin', in W.H. Neuser (ed.), Calvinus Servus Christi. Die referate des Internationalen Kongresses fur Calvinforschung vom 25. bis 28. August 1986 in Debrecen, pp. 73-106, Presseabteilung des Raday-Kollegiums, Budapest.

Van 't Spijker, W., 2004, Bij Calvijn in de leer. Een handleiding bij de Institutie, Den Hertog, Houten.

Wilcox, P.J., 1993, 'Restoration, reformation and the progress of the Kingdom of Christ: Evangelisation in the thought and practice of John Calvin, 1555-1564', PhD thesis, University of Oxford. 